\title{
PELAYANAN INFORMASI PERPUSTAKAAN BERBASIS MOBILE
}

\author{
M. Ali Nurhasan Islamy \\ Pustakawan Institut Seni Indonesia Surakarta \\ Email: ali_enhai@yahoo.com
}

\begin{abstract}
ABSTRAK
Kemajuan dalam jaringan teknologi informasi dan komputer selama beberapa dekade terakhir telah mengubah koleksi dan layanan perpustakaan. Sekarang, pemustaka secara rutin memperoleh informasi online sepanjang perjalanan menuju perpustakaan. Pengunjung perpustakaan secara fisik telah berubah dengan pergeseran dominan ke format online. Aplikasi layanan berbasis mobile sangat dapat diterapkan dalam perpustakaan di Indonesia. Salah satu software yang dapat diterapkan adalah Wireless Application Protocol (WAP), merupakan suatu protocol yang memungkinkan internetdapat diakses dengan perangkat mobile seperti ponsel atau handphone, android, smartphone dan perangkat wireless lainnya. Aplikasi WAP(Wireless Application Protocol) sepertinya lebih memudahkan pemustaka mengakses katalog secara mobile yang ada di perpustakaan dengan menggunakan Handphone, Android, smartphone,Iphone dan telepon seluler sejenis yang mempunyai aplikasi wireless. Proses pengaksesan dengan alat komunikasi tersebut di atasdapat dilakukan dimanapun dan kapanpun tanpa terbatas dengan ruang dan waktu.
\end{abstract}

Kata Kunci: Layanan Informasi, Perpustakaan, Mobile

\section{PENDAHULUAN}

Pada era saat ini teknologi informasi berkembang sangat pesat. Berita dan informasi kini sudah menjadi salah satu kebutuhan yang sulit kita kesampingkan, yang menjadi kebutuhan kita sehari-hari. Perkembangan tekonologi dunia yang begitu pesat memaksa kita terus berlomba-lomba meng-update informasi terbaru, namun ada juga agar tidak dikatakan ketinggalan zaman. Dalam perkembangannya, industri media mengalami transformasi yang mengarah pada pemenuhan gaya hidup masyarakat modern yang cenderung mobile. Tak terkecuali di Indonesia, beberapa perusahaan media ternama kini mulai melirik dunia internet mobile guna mengembangkan pangsa pasarnya.

Di Negara Indonesia sendiri tercatat ada banyak perusahaan media yang mencoba keberuntungannya dengan membuka portal layanan berita yang dapat diakses melalui perangkat mobile. Beberapa diantaranya yang sudah cukup popular (http://ponselfreak. blogspot. com 2017/02/referensi-mobile -newsportal.html), contohnya seperti :

1. Detik.com

Situs ini merupakan salah satu pelopor situs berita on-line di Indonesiayang dapat diakses langsung dari ponsel di alamat 
http://m.detik.com Berbekal nama besarnya yang sudah dikenal di dunia web, Detik.commenyajikan sebagian besar konten berita-beritanya dalam kemasan mobile.

Penyajiannya pun cukup menarik, berbagai informasi seperti politik, ekonomi dan olahraga bisa dengan mudah diperoleh dari situs ini. Dukungan jaringan peliputan yang luas menjadikan Detik.com mampu menyuguhkan berita-berita terbaru secara cepat dan aktual.

2. Vivanews.com

Vivanews adalah portal berita yang baru setahun berdiri dan merupakan bagian dari jaringan perusahaan media milik grup usaha Bakrie yang di dalamnya juga bernaung dua perusahaan stasiun televisi swasta nasional ANTV dan TV-ONE.

Vivanews memiliki tampilan yang begitu minimalis dan nyaris tanpa iklan. Suguhan beritanya pun cukup informatif dan up-to-date. Sayang, penyajian ulasannya yang cenderung singkat, membuat informasi yang didapat seringkali tidak terasa menyeluruh. Vivanews dapat langsung diakses via ponsel di alamat http://m.vivanews.com

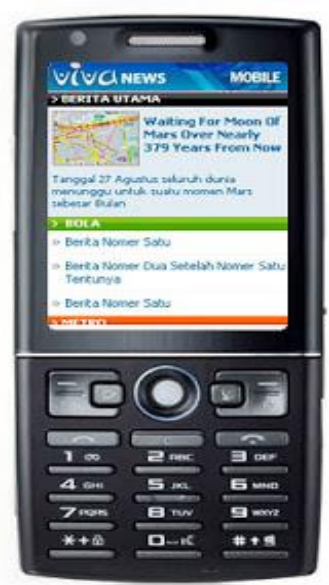

\section{Gambar 1. Situs Vivanews.com dalam menampilkan informasi}

Kebutuhan akan sesuatu informasi juga menjadi kebutuhan setiap hari setiap individu untuk memecahkan permasalahan mereka, dari yang bersifat hiburan sampai yang bersifat akademik. Pada institusi seperti perpustakaan, kemajuan dalam jaringan teknologi informasi dan komputer selama beberapa dekade terakhir telah mengubah koleksi yang pada awalnya tercetak menjadi digital atau elektonik, dan layanan perpustakaanpun dapat dilakukan secara online. Pada era sekarang, pemustaka dapat secara rutin memperoleh informasi online sepanjang perjalanan menuju perpustakaan.

Penggunaan perpustakaan atau pengunjung perpustakaan secara fisik telah berubah dengan pergeseran dominan ke format online, karena 
transaksi referensi telah menurun. Namun, meskipun banyak pemustaka belajar mandiri (online) dan pencarian informasi secara mandiri, mereka juga menginginkan instruksi pada pencarian literatur dan bantuan informasi pada saat mereka membutuhkan informasi. Pemustaka menghargai kontak pribadi dengan staf perpustakaan dalam menyelesaikan masalah mereka.

Menurunnya kunjungan ke perpustakaan dan kebutuhan untuk terus mendapatkan bantuan informasi secara tatap muka menuntut pustakawan untuk menciptakan cara-cara baru untuk membawa layanan kepada pemustaka. Pada awal tahun 1970-an dan 1980-an, Swope dan Katser, serta Ford menganjurkan konsep mengambil layanan referensi ke lokasi di luar perpustakaan. sebuah survei tahun 2004 yang dilakukan oleh Asociation Research Library (ARL) melaporkan bahwa empat puluh satu perpustakaan di seluruh negara menyediakan layanan atau jasa di ruangan lain di luar perpustakaan. Beberapa perpustakaan universitas telah mengatur layanan referensi sebagai layanan keliling di asrama mahasiswa. Perpustakaan lainnya menyediakan layanan tatap muka di berbagai pusat kegiatan universitas, ruang belajar, dan lokasi lain di mana mahasiswa berkumpul. Ruang kelas, kantor, laboratorium komputer, atau ruang terbuka di gedung-gedung kampus juga menjadi lokasi layanan perpustakaan ditempat. Virginia Tech melangkah lebih jauh dengan mendirikan program College Library. Mereka telah memindah kantor perpustakaan ke perguruan tinggi yang dipilih hampir penuh waktu dan menciptakan perpustakaan "cabang virtual".

Beberapa contoh tersebut di atas telah memperluas layanan di luar gedung perpustakaan atau menawarkan layanan referensi di lokasi kampus lain. Walaupun tidak semua perpustakaan dapat melaksanakan layanan referensi tersebut dengan sukses,namun hal ini telah terjadwalkan dan layanan di luar perpustakaan merupakan cara baru untuk menyediakan layanan yang berpusat pada pemustaka. Seperti yang disampaikan oleh Leonard (2014) “jika pelanggan cenderung untuk mengunjungi perpustakaan, maka pustakawan harus pergi ke pelanggan mereka".

Perpustakaan memang telah menyediakan berbagai sumber daya, akan tetapi karena jarak fisik telah mengurangi kemudahan akses langsung ke layanan referensi. Kemudian, untuk 
menjembatani kesenjangan tersebut telah diluncurkan sebuah program yang disebut Mobile Layanan Referensi, program ini mulai dikembangkan pada semester musim gugur pada tahun 2006, tujuan program ini untuk memberikan layanan bantuan informasi ditempat selama beberapa jam kantor setiap minggunya.

Aplikasi layanan berbasis mobile sangat bisa diterapkan dalam lingkungan pendidikan di Indonesia. Salah satu software yang dapat diterapkan adalah Wireless Application Protocol (WAP) merupakan suatu protocol yang memungkinkan internetdapat diakses dengan perangkat mobile seperti ponsel atau handphone, android, smartphone dan perangkat wireless lainnya. WAP membawa informasi secara online melalui internetlangsung menuju Ponsel atau Handphone. Dengan adanya WAP, berbagai informasi dapat diakses setiap saat dengan menggunakan ponsel atau handphone(Ibrahim, 2010: 189-205).

Perkembangan ini sangatlah membantu dalam menyajikan informasi yang cepat dan efisien dengan pengaksesan internet melalui perangkat mobile. Meski perangkat mobile merupakan small device dengan layar penyajian yang terbatas, tetapi penyajian informasi tidak kalah optimal layaknya informasi yang diakses dari personal computer. Dengan aplikasi WAP untuk memperluas akses katalog online, transaksi perpustakaan seperti pemesanan buku yang dapat diakses secara mobile seperti ponsel atau handphone. Berdasarkan data sebanyak $70 \%$ dari total seluruh penduduk di Indonesia menggunakan handphone seluler. (Available:

http://www.majalahindonesia.com/ divakar_goswami.htm.) atau sekitar 150 juta penduduk Indonesia menggunakan handphone seluler. Berikut ini adalah perkembangan dunia digitalIndonesia (https://id. techinasia. com/laporanpengguna-website- mobile- mediasosial-indonesia) 2018:

1) 72,7 juta pengguna aktif internet

2) 72 juta pengguna aktif media sosial, dimana 62 penggunanya mengakses media sosial menggunakan perangkat mobile.

3) 308,2 juta pengguna handphone Sedangkan menurut Muhammad Chandrataruna (2011) yang disampaikan di VIVAnews secara continue terjadi pertumbuhan penjualan handphone seluler terus meningkat pada akhir 2018, seperti terlihat pada tabel berikut: 
Tabel 1

\section{Penjualan Hanphone Seluler, 2018}

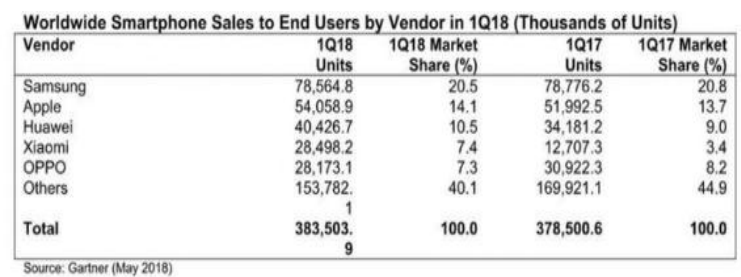

(Sumber: https://tekno.kompas.com2018) Melihat tabel di atas, dengan kenyataan demikian dapat menjadi peluang bagi institusi pendidikan seperti perpustakaan untuk menyelenggarakan proses transfer atau penyampaian informasi. Dengan memanfaatkan mobile. Perpustakaan adalah bagian yang tidak terlepas dari mahasiswa, dimana sebagai tempat menyediakan literatur-literatur yang mendukung kegiatan akademik perkuliahan. Selain mahasiswa, dosen sangat membutuhkan perpustakaan yang menyediakan literatur-literatur untuk mendukung pengajaran, penelitian dan pengabdian dosen pada masyarakat. Untuk itu, dosen dan mahasiswa merupakan bagian dari dunia pendidikan yang akan menggunakan layanan perpustakaan.

Sangat dibutuhkan suatu model baru untuk memberikan layanan perpustakaan yang ideal yaitu dapat memberikan informasi kepada pengguna dengan lebih efisien, efektif sehingga pengguna tidak merasa kecewa. Aplikasi teknologi WAP dalam memberikan layanan mobile kepada pengguna, sehingga semua akses perpustakaan dapat dilakukan di manapun dengan teknologi WAP (Ipad dan Ponsel atau Handphone, Android, Smartphone).

\section{PEMBAHASAN}

\section{Teknologi Informasi}

Teknologi informasi sudah jelas dapat diterapkan di perpustakaan perguruan tinggi. Sistem informasi perpustakaan mengenai sarana pendukung di bidang pendidikan adalah salah satu yang dibutuhkan untuk siapapun yang ingin mendapatkan informasi mengenai hal tersebut pada suatu daerah. Sistem informasi yang berbasis mobile dapat ditambahkan juga (augmented) informasi lain dalam bentuk teks, gambar, audio, secara virtual. Selain itu dikembangkan juga database online dan koneksi database server dengan dengan perangkat mobile/smartphone.

Namun, sebelum perpustakaan menetapkan tujuan dan ruang lingkup layanan, sebaiknya ditentukan terlebih dahulu sumber daya yang dibutuhkan,mengidentifikasi tindakan yang harus dilakukan, dan diharapkan memberikan kemudahan akses dan penggunaan sumber daya dan jasa perpustakaan bagi pemustaka berbasis mobile ini.

Program Studi Perpustakaan dan Sains Informasi Universitas Wijaya Kusuma Surabaya 


\section{Perpustakaan}

Dalam The Oxford Dictionary English, perpustakaan atau library didefinisikan sebagai tempat buku-buku yang diatur untuk dibaca dan dipelajari atau dipakai sebagai bahan rujukan.

Sedangkan menurut Yusuf dan Suhendar menyatakan bahwa perpustakaan adalah suatu tempat yang didalamnya terdapat kegiatan penghimpunan, pengelolaan, dan penyebarluasan (pelayanan) segala macam informasi, baik yang tercetak maupun yang terekam dalam berbagai media seperti buku, majalah, surat kabar, film, kaset, tape recorder, video (Yusuf, 2007).

Perpustakaan sebagai pusat informasi bagi kalangan intelektual, tentunya harus menerapkan teknologi informasi yang up tu date jika akan tetap menjadi idola pemustaka dalam melayani informasi. Teknologi yang bias diharapkan pada saat ini adalah teknologi informasi perpustakaan yang sewaktu-waktu dapat diakses kapanpun dan di manapun berada. Salah satu aplikasi yang dapat diterapkan yakni teknologi perpustakaan berbasis mobile WAP (Wireless Application Protocol).
3. Teknologi WAP (Wireless Application

Protocol)

\section{a. Pengertian WAP (WirelessAplication \\ Protocol)(www.ilmu komputer.com diakses 5 Nopember 2017)}

WAP adalah suatu protocol aplikasi yang memungkinkan internet dapat diakses oleh ponsel dan perangkat wireless lainnya. WAP membawa informasi online melewati internet langsung menuju ponsel atau clint WAP lainnya. Dengan adanya WAP, berbagai informasi dapat diakses setiap saat hanya dengan menggunakan ponsel.

\section{b. Keuntungan dan Kelemahan WAP}

Terdapat keuntungan standar WAP:

1) Tidak adanya kepemilikan metode dalam mengakses internet dengan standar WAP baik pada isi maupun layanan.

2) Network yang independent karena WAP bekerja pada seluruh jaringan seluler yang ada, seperti CDPD, CDMA, GSM, PDC, PHS, TDMA, FLEX, ReFLEX, Iden, TETRA, DECT, Data TAC, Mebitex, dan jaringan seluler masa depan yang saat ini sedang dikembangkan seperti GPRS dan $3 \mathrm{G}$.

Program Studi Perpustakaan dan Sains Informasi Universitas Wijaya Kusuma Surabaya 
3) Metode WAP telah diadopsi oleh hampir $95 \%$ produsen telepon seluler di dunia dalam memanfaatkan wireless internet access dan sedang diimplementasikan pada semua frekuensi.

4) WAP suatu standar protocol dan aplikasinya, yakni WAP browser yang dapat digunakan pada seluruh sistem operasi terkenal termasuk Palm OS, EPOC, Windows SE, FLEXOS, OS/9, Java OS, dan sebagainya.

5) Dengan menggunakan teknologi GPRS, perhitungan akses dihitung berdasarkan jumlah bit yang terkoneksi yang harganya Rp. 20 per kilo byte.

Terdapat kelemahan WAP :

1) Konfigurasi telepon selular untuk service WAP masih termasuk sulit

2) Jumlah telepon selular yang mendukung WAP masih terhitung sedikit.

3) Protokol lain seperti SIM Application Toolkit dan $\operatorname{MexE}$ (Mobile Station Application Execution Envirovment) secara luas didukung dan didesain untuk bersaing dengan WAP.

\section{c. Perbedaan WAP dan WEB}

Ditinjau secara teknis tentu saja ada berbagai perbedaan antara Internet (Word Wide Web, disingkat WEB) dengan mobile internet (WAP). Perbedaan-perbedaan tersebut terjadi akibat sifat dasar dari keduanya yang memang berbeda, khususnya dalam hal konektivitas dan mobilitas pengguna.

WAP lebih ditujukan untuk pengguna yang memiliki mobilitas tinggi atau mereka yang banyak berpindah tempat, sementara WEB untuk mereka yang sedang diam. Oleh sebab itu WAP memakai gelombang radio sebagai media pertukaraan datanya, sementara WEB menggunakan kabel.

Konektivitas modem ke jaringan telepon dalam WEB bersifat permanent / tetap karena menggunakan kabel, sedangkan konektivitas antara satu perangkat terminal data (yakni, telepon genggam) dengan perangkat WAP Gateway dalam WAP tidak bersifat permanent karena menggunakan gelombang radio. Tidaklah mengherankan bila konektivitas dalam WAP menjadi masalah yang cukup rumit untuk dipecahkan.

WEB:

1) Mengunakan jaringan kabel tetap. 
2) Komputer sebagai terminal data di sisi pengguna biasa digunakan dalam keadaan diam.

3) Kapasitas memori komputer sangat besar.

4) Ukuran layar display komputer sangat besar.

5) Pemrograman dalam bahasa HTML (Hypertext Mark-up Language)

WAP:

1) Menggunakan jaringan tanpa kabel (radio).

2) Telepon genggam sebagai terminal data di sisi pengguna biasa digunakan dalam keadaan bergerak.

3) Kapasitas memori telepon genggam sangatlah kecil.

4) Ukuran layar display telepon sangatlah kecil.

5) Pemrograman dalam bahasa WML (Wireless Mark-up Language).

Untungnya para pakar telah menemukan dua metode untuk mengatasi masalah konektivitas tersebut. Metode pertama, yang lebih sederhana dan lebih dulu muncul, dinamakan dengan CSD (Circuit Switch Data). Sedangkan metode kedua yang lebih mutakhir dikenal sebagai GPRS (General Packet Radio Service). Dengan metode CSD, transfer data dilakukan mirip seperti halnya transfer suara, tanpa ada perubahan data asli. Metode CSD ini, yang semula hanya mendukung kecepatan transfer $9.6 \mathrm{kbps}$, kini telah dikembangkan menjadi HSCSD (High Speed Circuit Switch Data) yang mempunyai kecepatan transfer $28.8 \mathrm{kbps}$, bahkan hingga 38.4 kbps.

Berbeda halnya dengan metode GPRS tidak dalam bentuk data asli tetapidalam bentuk potongan-potongan kecil data yang disebut packet. Kecepatan transfer data dengan GPRS bias mencapai 57.6 kbps bahkan sampai 115 kbps.

\section{Cara Kerja WAP}

Ada tiga bagian utama dalam akses WAP, yaitu perangkat wireless yang mendukung WAP, WAP Gateway sebagai perantara dan server sebagai sumber dokumen. Dokumen yang berada dalam web server dapat berupa dokumen HTML maupun WML. Dokumen WML khusus ditampilkan melalui browser dari perangkat WAP. Sedangkan dokumen HTML yang seharusnya ditampilkan melalui web browser, sebelum dibaca melalui browser WAP diterjemahkan terlebih dahulu oleh gateway agar dapat menyesuaikan dengan perangkat WAP. 


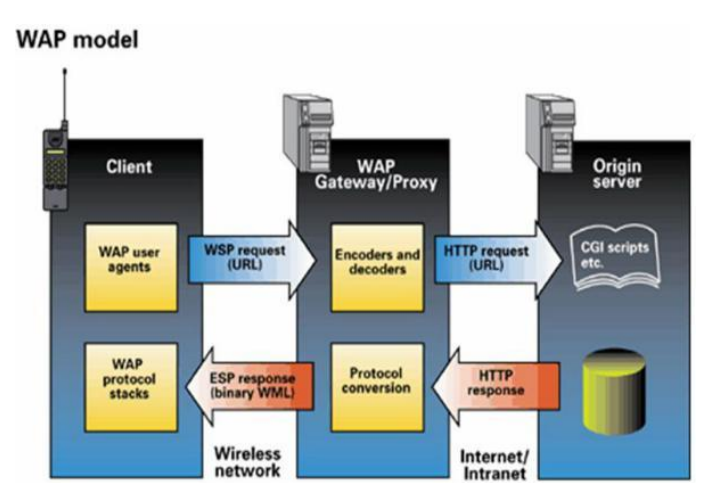

Gambar 2. Cara KerjaWAP (sumber: Mira Afrina, Ali Ibrahim, 2017)

Pada saat ini ponsel ingin meminta sebuah informasi yang ada di server, ponsel harus melewati WAP gateway dulu. Begitu juga sebaliknya. Proses pengiriman informasi dari ponsel ke WAP Gateway dan sebaliknya menggunkan jaringan komunikasi nirkabel (wireless) yang masih memiliki keterbatasan, terutama pada kecilnya bandwidth yang ada. Kecilnya bandwidth tersebut tidak cocok jika dipergunakan untuk memproses informasi lewat protocol HTTP. Protokol HTTP berfungsi untuk mengatur pengiriman informasi dari client menuju server dan sebaliknya. Untuk mengatasi kesenjangan ini diciptakanlah WAP Gateway. Fungsi WAP Gateway adalah untuk meneruskan permintaan informasi dari ponsel menuju server lewat HTTP request dan sebaliknya dari server menuju ponsel HTTP response.

\section{Arsitektur WAP}

Sistem WAP dibangun oleh beberapa elemen tertentu dalam suatu arsitektur yang khas.

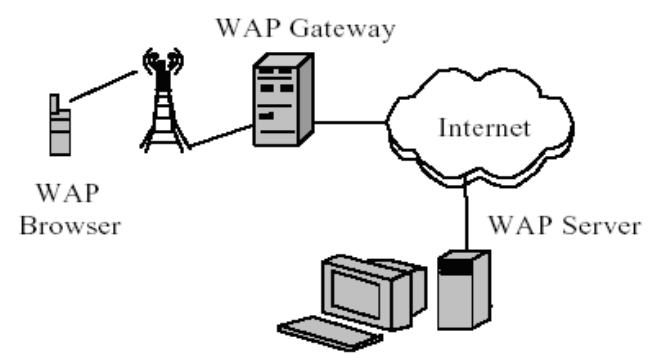

Gambar 3: Arsitektur WAP ( Tysno Nurhadi 2003 )

Pada sistem WAP ponsel merupakna ujung rantai jaringan, yang sekaligus berperan sebagai sistem disebut WAP client. Ponsel ini terhubung pada WAP gateway melalui gelombang radio frekeunsi 900/1800/1900 $\mathrm{mhz}$ Gsm (Global sistem For Mobile

\section{Communication)}

\section{Analisis Sistem dan Desain Sistem}

Pemustaka dalam melakukan proses pencarian informasi tentang koleksi terkadang masih manual yaitu di mana pengguna untuk mengakses atau mencari referensi harus datang ke perpustakaan atau dengan internet, tetapi masih terbatas untuk proses pencarian referensi. Tentunya hal itu sangat tidak efektif. Dengan perkembangan ICT, dan perkembangan kepemilikkan tekonologi mobile (Ipad, Ponsel atau Handphone) sudah saatnya perpustakaan dapat diakses di manapun dan kapanpun sehingga proses pencarian referensidi perpustakaan bisa dilakukan

Program Studi Perpustakaan dan Sains Informasi Universitas Wijaya Kusuma Surabaya 
dengan mudah, cepat dan efisien dan pengguna tidak harus datang ke perpustakaan karena semuanya sudah bisa di akses melalui teknologi mobile.

Dalam melakukan perancangan sistem beberapa tahapan yang harus dilakukan, agar aplikasi yang dibuat dapat berfungsi sesuai dengan yang diharapkan. Pada sistem, petugas akan input data seperti buku, jurnal, makalah dan hasil penelitian. Setelah di input maka akan masuk ke dalam database melalui web server. Pemakai atau user dengan mudah, cepat, efisien dan efektif untuk mendapatkan referensi atau informasi.

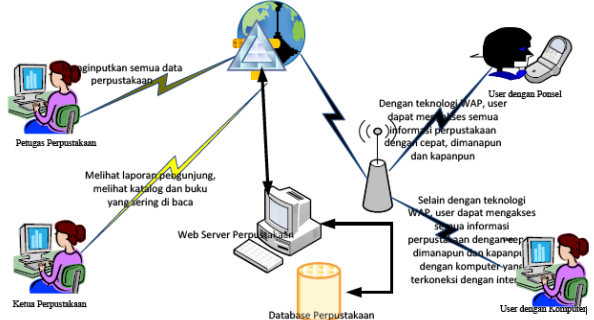

\section{Gambar 4: Desain Sistem Informasi Perpustakaan Dengan Basis WAP (Mobile)}

(sumber: Mira Afrina, Ali Ibrahim, 2017)

\section{KESIMPULAN}

Perpustakaan perguruan tinggi dihadirkan untuk mendukung tridharma perguruan tinggi yakni pendidikan, penelitian dan pengabdian msyarakat. Untuk memaksimalkan fungsi dari perpustakaan, maka harus dibuat manajemen dan strategi yang baik, sehingga informasi di perpustakaan mudah untuk diakses oleh masyarakat.

$$
\text { Aplikasi }
$$

\section{WAP(Wireless}

Application Protocol) sepertinya lebih memudahkan pemustaka mengakses katalog secara mobile yang ada di perpustakaan dengan menggunakan Handphone, Android, smartphone,Iphone dan telephon seluler sejenis yang mempunyai aplikasi wireless. Proses pengaksesan dengan alat komunikasi tersebut di atasdapat dilakukan dimanapun dan kapanpun tanpa terbatas dengan ruang dan waktu. Dapat diakses ketika pemustaka berada di rumah, di mall, di kendaraan dan tempat-tempat manapun dan kapanpun selama terdapat jangkauan signal jaringan internet.

Aplikasi seperti inilah yang seharusnya selalu dikembangkan oleh perpustakaan sehingga perpustakaan tetap menjadi idola semua pemustaka terutama bagi intelektual perguruan tinggi.

\section{DAFTAR PUSTAKA}

Ibrahim, A. (2010) "Sistem Pemesanan Kamar Hotel Berbasis WAP,"Jurnal Sistem Informasi (JSI), vol. 2, no. 2, pp. 189-205, April.

Subrata, G.(2009) Perpustakaan Digital. Pustakawan Perpustakaan UM.

The Oxford Dictionary English 3rd edition, OUP Oxford (19 Aug. 2010) 
Yusuf, M. P. and Suhendra, Y. (2007).

"Pedoman

Penyelenggaraan

Perpustakaan Sekolah," Jakarta,

Media Prenada Media Group.

[Online].Available:

http://www.majalahindonesia.com/

divakar_goswami.htm.diakses pada

tanggal 2 Nopember 2018

http://cymcollection.blogspot.com/2017/10

/jurnal-sistem-informasi-

ringkasan.html"Pengembangan

Model Sistem Informasi Perpustakaan

dengan Teknologi Informasi Berbasis

Wireless Aplication Protocol

(WAP)",Mira Afrina, Ali Ibrahim, diakses pada tanggal 2 Nopember 2018

http://cymcollection.blogspot.com/20

$\underline{17 / 10 / \text { jurnal-sistem-informasi- }}$

ringkasan.html

https://id.techinasia.com/laporan-

pengguna-website-mobile-media-

sosial-indonesia, diakses pada tanggal

2 Nopember 2018

http://ponselfreak.blogspot.com/2010/02/e

ferensi-mobile-news-portal.html

diakses pada tanggal 2 Nopember

2017

https://tekno.kompas.com/read/2018/06/05

/16330097/penjualan-smartphone-

global-kembali-positif-satu-merek-

melesat,diakses pada tanggal 2

Nopember 2018

www.ilmu komputer.com diakses 5

Nopember 2017

Program Studi Perpustakaan dan Sains Informasi Universitas Wijaya Kusuma Surabaya 